\title{
ANALISIS PEMAHAMAN DAN PEMBINAAN NORMA SOPAN SANTUN MELALUI PKN PADA ANAK SEKOLAH GBI SUKMA MEDAN
}

\author{
Rizky Agassy Sihombing1, Jennie Febrina Hutagalung², Pristi Suhendro Lukitoyo ${ }^{3}$ \\ ${ }^{12}$ Program Studi Bilingual Pendidikan IPA, Fakultas Matematika dan Ilmu Pengetahuan Alam, Universitas Negeri \\ Medan, Sumatera Utara \\ ${ }^{3}$ Program Studi Pendidikan Sejarah, Fakultas Ilmu Sosial, Universitas Negeri Medan, Sumatera Utara \\ 1rizkyagassy@mhs.unimed.ac.id
}

\begin{abstract}
Abstrak
Tujuan penelitian ini adalah untuk mengetahui dan menganalisis pemahaman dan pembinaan yang cocok dilaksanakan dalam norma sopan santun melalui pembelajaran PKn pada anak sekolah minggu GBI Sukma Medan. Metode Penelitian yang digunakan adalah metode deskriptif kualitatif, teknik pengumpulan data menggunaan teknik observasi, wawancara dan dokumentasi. Obyek penelitian ini adalah kegiatan pembinaan norma sopan santun dalam pembelajaran PKn melalui teknik bercerita. Populasi penelitian adalah seluruh anakanak sekolah minggu GBI Sukma Medan yang terdiri dari kelas III-VI. Instrumen pengumpulan data adalah peneliti sendiri dengan bantuan pedoman observasi dan pedoman wawancara. Hasil yang diperoleh dari analisis data yang ditemukan bahwa anak-anak sekolah minggu GBI Sukma Medan kurang memahami konsep norma sopan santun serta penerapan nilai norma sopan santun dalam kehidupan sehari-hari melalui pembelajaran PKn yang telah mereka pelajari sebelumnya.
\end{abstract}

\section{Kata Kunci: PKn, Pembinaan, Norma Sopan Santun}

\begin{abstract}
The purpose of this study was to determine and analysis the understanding and guidance that is suitable to be implemented in the norms of courtesy through Civics learning in Sunday school children at GBI Sukma Medan. The research method used is descriptive qualitative method, data collection techniques using observation, interview and documentation techniques. The object of this research is the activity of fostering norms of courtesy in Civics learning through storytelling techniques. The study population was all children of the Sunday School at GBI Sukma Medan, which consisted of class III-VI. The data collection instrument is the researcher himself with the help of observation guidelines and interview guidelines. The results obtained from the data analysis found that Sunday school children at GBI Sukma Medan did not understand the concept of the norms of courtesy and the application of the norm values of courtesy in daily life through Civics learning that they had previously learned
\end{abstract}

Keywords:, Civic, Guidance, Norms of Courtesy

\section{PENDAHULUAN}

Pembelajaran dilakukan dan didesain untuk membelajarkan para siswa, artinya siswa ditempatkan sebagai subjek belajar. Agar dapat mencapai tujuan pendidikan dilaksanakan aktivitas pembelajaran. Sekolah sebagai kepanjangan tangan pemerintah untuk mencapai tujuan pendidikan nasional wajib melaksanakan amanah dari Undang-Undang Sistem Pendidikan Nasional (UU Sisdiknas) Nomor 20 Tahun 2003, yang menghendaki penyelenggaraan pendidikan di Sekolah Dasar (SD), berfungsi memberikan bekal dasar, pengembangan kemapuan pikir, keterampilan, dan karakter peserta didik untuk kehidupan masa depannya. Karakter menjadi salah satu parameter kualitas suatu bangsa. Generasi bangsa yang berkarakter akan menjunjung tinggi nilai luhur bangsa dan negara.

Jika kita lihat tujuan pendidikan nasional berdasarkan UU Nomor 20 tahun 2003 tentang Sistem Pendidikan Nasional, yang berbunyi "Pendidikan nasional berfungsi mengembangkan kemampuan dan membentuk watak serta peradaban bangsa yang bermartabat dalam rangka 
mencerdaskan kehidupan bangsa, bertujuan untuk berkembangnya potensi peserta didik agar menjadi manusia yang beriman dan bertakwa kepada Tuhan Yang Maha Esa, berakhlak mulia, sehat, berilmu, cakap, kreatif, mandiri, dan menjadi warga negara yang demokrasi serta bertanggung jawab". Tujuan pendidikan nasional tersebut telah jelas bahwa pendidikan karakter sudah merupakan bagian dari proses pendidikan kita. Namun pada implementasi di lapangan pendidikan karakter tersebut tidak dilakukan secara teritegrasi dalam pendidikan di sekolah.

Pendidikan anak merupakan tanggungjawab bersama antara orang tua dan sekolah. Orang tua tidak dapat sepenuhnya membebankan proses pendidikan anaknya pada sekolah. Oleh karena itu kerjasama antara sekolah dan orang tua di rumah bahkan masyarakat lingkungan dimana anak tinggal dalam mendidikan anak agar berkembang dan membentuk karakter siswa yang kuat.

Kondisi di Indonesia pada beberapa tahun terakhir memperlihatkan adanya penurunan karakter pada generasi muda, terlebih lagi terhadap anak-anak dibawah umur. Beberapa kasus diantaranya seperti adanya kasus bully terhadap anak lain, mengucapkan kata-kata yang tidak pantas diucapkan, terlebih lagi terhadap anak-anak yang masih dibawah umur, mencoba menonton pornografi karena tidak adanya pengawasan terhadap anak dibawah umur, lebih banyak bermain game online, dibanding dengan belajar atau membantu orang tua. Anak-anak dibawah umur zaman sekarang pun, terlebih lagi dimasa pandemi ini, banyak diantara mereka yang mencobacoba untuk ikut kegiatan tawuran dan juga demo yang belakangan ini terjadi di negara kita. Dengan demikian, pendidikan dan pengamalan nilai-nilai karakter pada masa kanak-kanak masih perlu diajarkan dan dioptimalkan.

Salah satu nilai moral dasar yang harus dimiliki oleh manusia adalah karakter sopan santun (Lickona, 2009). Sopan santun merupakan tata krama dalam kehidupan sehari-hari sebagai cerminan kepribadian dan budi pekerti luhur (Zuriah \& Yustianti, 2007). Menurut Angelina (2013), kontrol diri menjadi faktor penyebab kecenderungan perilaku menyimpang pada remaja, kondisi ini disebabkan remaja belum mampu mengatur stimulus dan mempertimbangkan konsekuensi yang dihadapi sehingga tindakannya belum tepat.

Siti dan Nihayatul (2013) mengatakan bahwa Pancasila menjadi pedoman kehidupan bermasyarakat dan bernegara, lewat nilai, moral, norma dan etika yang ditanamkan sebagai bagian dari landasan filosofis serta kepribadian negara-bangsa. Dengan begitu, ditemukan kesesuaian nilai kepribadian tersebut dengan wilayah birokrasi pada ranah Governance, sekaligus juga "penjaga" regulasi pada level etika bernegara-berbangsa. Dari hasil analisis K Bertens (2004: 6) disimpulkan bahwa etika memiliki tiga posisi, yaitu sebagai (1) sistem nilai, yakni nilai-nilai dan norma-norma yang menjadi pegangan bagi seseorang atau suatu kelompok dalam mengatur 
tingkah lakunya, (2) kode etik, yakni kumpulan asas atau nilai moral, dan (3) filsafat moral, yakni ilmu tentang yang baik atau buruk.

Pemahaman Pancasila selain sebagai ideologi, pandangan hidup, kepribadian, dan kebudayaan negara-bangsa adalah kristalisasi nilai, standar etika, serta manifestasi norma, dalam aspek moralitas pikiran-tindakan-ucapan. Dengan demikian, seluruh ruang kehidupan bermasyarakat-bernegara berada dalam koridor landasan ideologis Pancasila. Hal ini merujuk pada arti kata ideologi itu sendiri, Althusser sendiri menekankan pula bahwa ideologi adalah relasi imajiner individuindividu terhadap kenyataan real eksistensi mereka, yaitu ideologi sebagai kekuatan material dalam masyarakat yang menyerap individu-individu sebagai subjek dalam ideologi tertentu, misalnya relasi imajiner guru-murid menghasilkan praktik material tentang cara berinteraksi antara guru dan murid (Adian, 2005).

Pendidikan etika atau moral pada anak merupakan tanggungjawab bersama antara orang tua dan sekolah. Orang tua tidak dapat sepenuhnya membebankan proses pendidikan anaknya pada sekolah. Oleh karena itu kerjasama antara sekolah dan orang tua di rumah bahkan masyarakat lingkungan dimana anak tinggal dalam mendidikan anak agar berkembang dan membentuk karakter siswa yang kuat dan baik (Sunu dan Ujiningsih, 2010).

Sebagai pendidik di sekolah, guru memiliki tanggung jawab secara moral untuk mengarahkan dan membantu peserta didik berperilaku baik, melindungi mereka dari hal-hal yang akan merusak kepribadiannya. Dibawah bimbingan guru, peserta didik dibimbing tata cara bersosialisasi sesuai dengan norma, moral dan etika masyarakat di mana ia hidup. Amanah ini hendaknya dipegang teguh dan dijalankan dengan sepenuh hati oleh para pendidik di sekolah. Ini dikarenakan peserta didik merupakan tanggung jawab guru untuk diarahkan pada hal-hal kebaikan, mengingat pada usia ini peserta didik sedang mengalami perkembangan yang saat peka terhadap pengaruh-pengaruh dari lingkungan.

Guru wajib memahami dengan baik visi, misi dan tujuan pembelajaran PKn, memahami konsep-konsep yang akan membantunya untuk membinakan perilaku etika sopan santun, seperti konsep tentang nilai, moral, dan etika, konsep tentang berbagai pendekatan, model pendidikan nilai, dan model pembelajaran lainnya, serta media pembelajaran yang akan mendukung proses pembinaan etika sopan santun.

Hasil dari belajar adalah perubahan tingkah laku siswa baik terkait pemahaman, keterampilan maupun aspek lain pada mata pelajaran di sekolah, maupun dilihat dari aspek etika sopan dan santun dari siswa. Penyebab etika sopan santun yang kurang memuaskan dapat berasal dari dalam diri siswa dan berasal dari lingkungan siswa belajar. Lingkungan keluarga, masyarakat 
dan sekolah merupakan salah satu faktor yang mempengaruhi etika sopan santun siswa dari luar. Slameto (2010) mengatakan bahwa salah satu faktor sekolah yang mempengaruhi hasil belajar adalah model pembelajaran.

Jadi pendidikan adalah faktor utama dalam menciptakan keadaban dan kebajikan (civic virtue) bagi bangsa. Keadaban dalam bersikap, keadaban dalam keluarga, forum, lingkungan, pemerintah, keadaban dalam berkomunikasi, keadaban dalam berinteraksi, keadaban dalam mengambil keputusan/ kebijakan, keadaban dalam memimpin, bahkan sampai yang dipimpin harus mempunyai nilai keadaban. Sehingga semua saling bersinergi, saling menjaga, saling mengontrol, saling mengingatkan dan saling mengamankan dari hal yang negatif.

Hasil observasi yang dilakukan di GBI Sukma Medan khususnya untuk siswa sekolah minggu yang terdiri dari kelas III-VI pada pembelajaran Pendidikan Kewarganegaraan khususnya mengenai etika sopan santun, proses penelitian untuk mengetahui tingkat pemahaman siswa sekolah minggu dengan cara melakukan wawancara terhadap beberapa anak terkait dengan pemahaman norma sopan dan santun. Penelitian bertujuan untuk mengetahui pemahaman dan cara pembinaan etika sopan santun melalui pembelajaran pendidikan kewarganegaraan pada siswa sekolah minggu GBI Sukma Medan yang terdiri dari kelas III-IV.

\section{METODE}

Penelitian ini menggunakan metode deskriptif kualitatif. Metodologi adalah proses, prinsip, dan prosedur yang kita gunakan untuk mendekati problem dan mencari jawaban (Mulyana, 2008, hal. 145). Penelitian deskriptif merupakan metode mengumpulkan data berdasarkan faktor-faktor yang menjadi pendukung terhadap objek penelitian, kemudian menganalisa faktor-faktor tersebut untuk dicari peranannya (Arikunto, 2010, hal. 151). Penelitian kualitatif merupakan penelitian yang berhubungan dengan ide, persepsi, pendapat, kepercayaan orang yang akan diteliti dan kesemuanya tidak dapat di ukur dengan angka. Dalam penelitian ini, teori yang digunakan dalam penelitian tidak dipaksakan untuk memperoleh gambaran seutuhnya mengenai suatu hal menurut pandangan manusia yang telah diteliti (Sulistyo-Basuki, 2006, hal. 24). Sementara itu, menurut Ditha (2018), metode penelitian kualitatif merupakan suatu penelitian yang digunakan untuk meneliti pada objek yang alamiah dimana peneliti adalah sebagai instrumen kunci, teknik pengumpulan data dilakukan secara gabungan, analisis data bersifat induktif, dan hasil penelitian kualitatif lebih menekankan makna daripada generalisasi.

Teknik dalam pengumpulan data menggunakan teknik observasi, wawancara secara mendalam dan dokumentasi. Obyek penelitian adalah adalah kegiatan pembinaan norma sopan santun dalam pembelajaran PKn melalui teknik bercerita. Populasi penelitian adalah seluruh anak- 
anak sekolah minggu GBI Sukma Medan yang terdiri dari kelas III VI. Instrumen pengumpulan data adalah peneliti sendiri dengan bantuan pedoman observasi dan dalam pedoman wawancara. Instrumen pengumpulan data berupa pedoman observasi dan pedoman wawancara yang telah dibuat sebelum terjun ke lapangan (GBI Sukma Medan). Analisis data dilakukan saat di lapangan dan sesudah di lapangan. Data dianalisis secara narasi dengan pemaknaan secara mendalam.

\section{HASIL DAN PEMBAHASAN}

\section{Pemahaman Pendidikan Kewarganegaraan Pada Anak Sekolah Minggu GBI Sukma Medan}

Berdasarkan temuan penelitian, anak-anak sekolah minggu GBI sukma masih belum sepenuhnya memahami konsep Pendidikan Kewarganegaraan. Hal ini dibuktikan oleh jawaban anak-anak GBI sukma atas pertanyaan peneliti pada saat melakukan wawancara.

Berikut ini penuturan hasil wawancaranya,

Peneliti: “Apakah adik sudah belajar Pendidikan Kewarganegaraan di sekolah?”

Anak A: "Sudah kak"

Begitu juga dengan beberapa anak yang lainnya, semua anak yang ikut diwawancara menjawab bahwa mereka sudah belajar Pendidikan Kewarganegaraan (PKn). Selanjutnya peneliti kembali bertanya.

Peneliti: "Sejak kapan adik sudah belajar Pendidikan Kewarganegaraan?"

Nah, lain halnya dengan pertanyaan ini, beragam jawaban diberikan oleh anak-anak sekolah minggu GBI Sukma.

Anak A: "Kalau saya dari kelas 2 SD kak"

Anak B: "Saya sudah belajar PKN dari kelas 1 SD kak"

Anak C: "Di sekolah saya diajarkan PKN dari kelas 3 SD kak"

Jawaban yang diberikan oleh setiap anak berbeda-beda. Namun kebanyakan anak menjawab bahwa mereka sudah belajar Pendidikan Kewarganegaraan sejak mereka kelas 1 SD. Peneliti kembali mengajukan pertanyaan.

Peneliti: "Menurut adik apakah Pendidikan Kewarganegaraan itu"?

Begitu juga dengan pertanyaan ini, ada beragam pendapat yang diberikan oleh anak sekolah minggu GBI Sukma. Berikut beberapa jawaban dari anak sekolah minggu GBI Sukma. Anak A: "Menurut saya PKN adalah pendidikan yang dapat mengajarkan anak-anak tahu akan negara kita"

Anak B: "PKN itu pelajari tentang Pancasila kak"

Anak C: "Belajar tentang hukum dan Pancasila kak" 
Anak D: "PKN itu pelajaran untuk mengetahui hukum-hukum dan peraturan yang berlaku di Indonesia"

Dari wawancara diatas dapat kita lihat bahwa kebanyakan dari mereka menjawab Pendidikan Kewarganegaraan adalah pelajaran yang mempelajari tentang hukum dan peraturan negara. Hal ini membuktikan bahwa mereka mengenal hukum maupun aturan-aturan negara, dan UUD saja. Mereka belum mengerti implementasi dan nilai-nilai dari setiap butir-butir Pancasila. Karena sebenarnya Pendidikan Kewarganegaraan dituntut untuk dapat mengacu pada pendidikan karakter anak-anak bangsa.

Pendidikan Kewarganegaraan (PKn) merupakan bidang kajian dalam konteks pendidikan nasional yang memiliki peran strategis untuk meningkatkan kembali wawasan kebangsaan, semangat nasionalisme. Karena itu, untuk memperkuat peran Pendidikan Kewarganegaraan (PKn), maka pemerintah mewajibkan diberikan pada setiap satuan pendidikan termasuk perguruan tinggi. Sebagaimana dalam pasal 37 ayat (1) Undang-Undang No.20 Tahun 2003 tentang Sistem Pendidikan Nasional bahwa "Pendidikan Kewarganegaraan dimaksudkan untuk membentuk peserta didik menjadi manusia yang memiliki rasa kebangsaan dan cinta tanah air”.

Karena itu, negara bertanggung jawab untuk mempersiapkan generasi muda yang memiliki wawasan kebangsaan yang tinggi dan juga memiliki semangat nasionalisme dalam kehidupan berbangsa dan bernegara. Sebagaimana Winataputra (2014), Secara holistic pendidikan kewarganegaraan bertujuan agar setiap warga Negara muda (young citizens) memiliki rasa kebangsaan dan cinta tanah air dalam konteks nilai dan moral Pancasila, nilai dan norma UndangUndang Dasar Negara Republik Indonesia Tahun 1945, nilai dan komitmen Bhinneka tunggal Ika, dan komitmen bernegara kesatuan Republik Indonesia. Oleh karena itu secara sadar dan terencana peserta didik sesuai dengan perkembangan psikologis. dan konteks kehidupannya secara sistemik difasilitasi untuk belajar berkehidupan demokrasi secara utuh.

\section{Konsep Pendidikan Karakter}

Menurut Suyanto (2010), karakter adalah cara berpikir dan berperilaku yang menjadi ciri khas tiap individu untuk hidup dan bekerja sama, baik dalam lingkup keluarga, masyarakat dan bangsa dan negara. Sementara, pendidikan karakter adalah pendidikan budi pekerti plus, yaitu yang melibatkan aspek pengetahuan (cognitive), perasaan (feeling), dan tindakan (action). Tanpa ketiga aspek ini, maka pendidikan karakter tidak akan efektif.

Menurut Kemendiknas (2010) nilai-nilai luhur adat dan budaya suatu bangsa Indonesia telah teridentifikasi menjadi 18 nilai karakter, yaitu: Religius, Jujur, Toleransi, Disiplin, Kerja Keras, Kreatif, Mandiri, Demokrasi, Rasa ingin tahu, Semangat Kebangsaan, Cinta Tanah Air, 
Menghargai Prestasi, Bersahabat/Komunikatif, Cinta Damai, Gemar Membaca, Peduli Lingkungan, Peduli Sosial, Tanggung Jawab. Perempuan memiliki karakter yang lebih baik dibanding laki-laki dikarenakan perempuan memiliki tingkat kontrol diri yang lebih tinggi dibandingkan dengan laki-laki (Cheung \& Cheung, 2008).

Dalam pengertian sederhana, menurut Muclas Samani dan Hariyanto (2011), pendidikan karakter adalah hal positif apa saja yang dilakukan guru dan berpengaruh kepada siswa yang diajarnya. Muclas Samani dan Hariyanto mengutip Winton bahwa pendidikan karakter adalah upaya sadar dan sungguh-sungguh dari seorang guru untuk mengajarkan nilai-nilai kepada para siswanya. Pendidikan karakter telah menjadi sebuah pergerakan pendidikan yang mendukung pengembangan sosial, pengembangan emosional, dan pengembangan etik para siswa. Merupakan suatu upaya proaktif yang dilakukan baik oleh sekolah maupun pemerintah untuk membantu siswa untuk mengembangkan inti pokok dari nilai-nilai etik dan nilai-nilai kinerja, seperti kepedulian, kejujuran, kerjinan, sportifitas, keuletan dan ketabahan, tanggung jawab, menghargai diri sendiri dan orang lain.

Sedangkan, pengertian nilai menurut Qiqi Yuliati (2014) adalah "segala hal yang berhubungan dengan tingkah laku manusia mengenai baik atauburuk yang diukur oleh agama, tradisi, etika, moral, dan kebudayaan yang berlaku dimasyarakat”. Sedangkan M. Asrori (2015) memaparkan, nilai sebagai sesuatu yang diyakini kebenarannya dan mendorong orang untuk mewujudkannya. Adanya nilai memungkinkan individu/ kelompok sosial membuat keputusan mengenai apa yang dibutuhkan atau sebagai sesuatu yang ingin dicapai

\section{Pemahaman Norma Sopan Santun Pada Anak Sekolah Minggu GBI Sukma Medan}

Berdasarkan temuan penelitian, anak-anak sekolah minggu GBI sukma masih belum sepenuhnya memahami konsep Pendidikan Kewarganegaraan. Hal ini dibuktikan oleh jawaban anak-anak GBI sukma atas pertanyaan peneliti pada saat melakukan wawancara.

Berikut ini penuturan hasil wawancaranya,

Peneliti: "Pada Pendidikan Kewarganegaraan (PKn) tentu adik pernah mendengar tentang norma kesopanan. Apa sih norma sopan santun itu?"

Anak A: "Ya kak, saya pernah mendengarnya bahkan mempelajari macam-macam norma. Menurut saya norma sopan santun adalah norma susila"

Anak B: "Saya pernah mmendengar nya kak, norma sopan santun adalah norma yang hukumnya berasal dari diri sendiri dan tidak tentu"

Anak C: "Menurut saya norma sopan santun adalah sikap sopan kepada siapa saja"

Anak D: "Norma kesopanan adalah norma yang wajib kita lakukan kepada siapa saja" 
Dari uraian berbagai jawaban yang disampaikan anak-anak Sekolah Minggu GBI Sukma dapat dilihat bahwa masih kurangnya pemahaman mereka mengenai norma sopan santun. Anakanak sekolah minggu banyak menyebutkan penerapan norma tersebut.

Zuriah (2007) mengemukakan bahwa sopan santun adalah sikap dan perilaku yang tertib sesuai dengan adat istiadat atau norma-norma yang berlaku di dalam masyarakat. Namun pada kenyataanya, dalam beberapa tahun terakhir ini budaya sopan santun khususnya di sekolah mengalami penurunan. Hal ini dapat dilihat dari generasi muda atau remaja yang cenderung kehilangan etika sopan santun terhadap teman sebayanya yang lebih tua maupun dengan gurunya. Peserta didik tidak lagi menganggap guru sebagai panutan, seorang yang memberikan ilmu dan pengetahuan yang patut dihormati dan disegani.

Marzuki dan Fatma A.S (2015: 59) mengungkapkan "Character education is a planned effort to make the student familiar, caring and the values that to be good learners" (Pendidikan karakter adalah usaha yang direncanakan untuk membuat peserta didik menjadi kenal, peduli dan menerapkan nilai-nilai demi menjadi pembelajar yang baik). Oleh karena itu pendidikan karakter perlu diberikan ke peserta didik sejak dini untuk menjadikan diri sebagai pribadi yang berjiwa karakter, mengingat bahwa nilai-nilai karakter anak bangsa saat ini sudah mulai luntur, khususnya pada kesopanan, kejujuran dan tanggung jawab.

Indikator nilai kesopanan (Inrawati Paramata, 2015, hal. 4) dapat dilihat dari sikap: (1) mengucapkan terima kasih jika diberi sesuatu baik dari orang tua maupun orang lain sekaligus mengajarkan menghargai jerih payah orang lain, (2) mengucapkan maaf jika bersalah untuk mengajarkan sportivitas dan berani mengakui kesalahan, (3) mengucapkan tolong ketika meminta diambilkan sesuatu, dengan begitu anak belajar untuk menghargai pertolongan atau bantuan orang lain, (4) menyapa, memberikan salam atau mengucapkan permisi jika bertemu orang lain mengajarkan pula perilaku ramah dan agar mudah bersosialisasi, (5) mengajarkan bagaimana berbudi bahasa yang baik misalnya tidak berteriak-teriak ataupun tidak memotong pembicaraan orang lain.

Karakter anak bangsa saat ini mulai memudar, satu diantaranya adalah lingkungan. Pergaulan lingkungan yang tidak baik dapat menyebabkan seseorang terdorong untuk melakukan hal yang sama yang dilakukan temannya sebagai wujud merasa diri hebat bisa melakukan hal demikian. Faktor pembentuk kepribadian dapat terjadi melalui faktor internal maupun faktor eksternal. Faktor internal tersebut dapat berupa kebutuhan psikologis (rasa aman, penghargaan, penerimaan, aktualisasi diri) dan kebutuhan pemikiran. Sedangkan faktor eksternal berupa faktor 
lingkungan (keluarga dan teman bermain / berkumpul), faktor sosial, pendidikan, maupun fakor figuritas.

Menurut Lickona (2013) dalam budaya jawa sikap sopan salah satunya ditandai dengan perilaku menghormati kepada orang yang lebih tua, menggunakan bahasa yang sopan, dan tidak memiliki sifat yang sombong. Sedangkan menurut Chazawi (2007) santun adalah satu kata sederhana yang memiliki arti banyak dan dalam berisi nilai-nilai positif yang dicerminkan dalam perilaku dan perbuatan positif. Perilaku positif lebih dikenal dengan santun yang dapat diimplementasikan pada cara berbicara, cara berpakaian, cara memperlakukan orang lain, cara mengekspresikan diri dimanapun dan kapanpun.

Menurut Mahfudz (2010), bahwa kurangnya sopan santun pada anak disebabkan oleh beberapa hal yaitu: faktor lingkungan dan kurangnya perhatian dari orang tua serta pengaruh dari perkembangan teknologi sehingga anak meniru perbuatan yang negatif. Maka dari itu peran orang tua dan guru sangat penting dalam upaya pembentukan karakter budaya sopan santun terhadap anak.

\section{Pembinaan Melalui Pengajaran Pendidikan Kewarganegaraan Mengenai Norma Sopan} Santun

Setelah peneliti mendapatkan hasil dari wawancara yang telah dilakukan, peneliti mendapatkan kesimpulan bahwa kebanyakan dari anak-anak sekolah minggu GBI Sukma belum mengetahui dengan baik terkait dengan norma sopan santun, sehingga peneliti melakukan peninjauan ulang pada permasalahan yang mengakibatkan kurangnya pemahaman anak-anak sekolah minggu GBI Sukma terkait dengan norma sopan santun yang sebelumnya sudah dipelajari di sekolah mereka, dan disini peneliti memberikan pembinaan secara langsung mengenai norma sopan santun dengan teknik bercerita.

Sehingga, ketika peneliti mengetahui permasalahan yang mengakibatkan kurangnya pemahaman anak-anak sekolah GBI Sukma mengenai norma sopan santun, peneliti melakukan pembinaan secara langsung mengenai norma sopan santun dengan teknik bercerita, tujuannya agar dapat meminimalisir permasalahan yang mengakibatkan anak-anak sekolah minggu GBI Sukma tidak memahami secara benar mengenai norma sopan santun.

Anak-anak sekolah minggu GBI Sukma sangat antusias dan sangat menyimak ketika peneliti melakukan pembinaan terhadap mereka. Ada beberapa anak yang mencatat dan menyimak dan ada juga anak yang hanya menyimak, karena kita tahu tiap-tiap anak memiliki cara belajar yang berbeda-beda. Disini, peneliti bercerita tentang apa itu sopan santun, apa hubungan antara norma sopan santun dengan Pendidikan Kewarganegaraan, bagaimana penerapan norma sopan 
santun yang baik dan benar, pelanggaran yang tidak boleh dilakukan dalam pelaksanaan norma sopan santun, serta memberitahukan mereka apa yang menjadi permasalahan sehingga mereka kurang memahami mengenai norma sopan santun.

Setelah itu, peneliti memberikan pembinaan kepada anak sekolah minggu GBI Sukma, dan kembali mengajukan pertanyaan seperti sebelumnya dengan wawancara, namun disini pertanyaan yang diajukan berbeda dari pertanyaan sebelumnya. Berikut pertanyaan yang telah diajukan kepada anak-anak sekolah minggu GBI Sukma,

Peneliti: "Nah setelah tadi kakak sudah memberikan pembinaan kepada kalian, kakak mau bertanya, ada beberapa pertanyaan yang harus kalian jawab ya adik-adik, nah setelah mendengar pembinaan dari kakak, apa itu norma sopan santun dan sebutkan satu contoh penerapannya?"

Anak A: "Norma sopan santun adalah sebuah serangkaian aturan yang sudah diberlakukan di dalam kehidupan dan lingkungan masyarakat atau keluarga, mengenai tingkah laku dan perbuatan yang dilakukan oleh seseorang. Contohnya adalah menghormati orang yang lebih tua daripada kita"

Anak B: "Iya kak benar seperti apa yang telah disampaikan oleh teman saya, contoh norma sopan santun itu adalah menerima pemberian seseorang dengan tangan kanan”

Anak C: "Kalau menurut saya contohnya itu mengenakan pakaian yang sopan kak"

Anak D: "Menurut saya kak contoh norma sopan santun itu tidak berkata-kata kotor"

Berdasarkan dari apa yang telah disampaikan oleh anak-anak sekolah minggu GBI Sukma, peneliti langsung mendapat kesimpulan, bahwasannya mereka sudah memahami dengan baik serta tahu penjelasan norma sopan santun dan contoh penerapan norma sopan santun dalam kehidupan sehari-hari, peneliti menyimpulkan bahwasannya pembinaan dengan teknik bercerita cocok dan sesuai diterapkan kepada anak-anak sekolah minggu GBI Sukma.

\section{Strategi Penanaman Norma Sopan Santun Melalui Pendidikan Kewarganegaraan}

Sopan Santun dalam Pembelajaran PKn strategi guru menanamkan karakter sopan santun dalam belajar PKn adalah dengan pendekatan dalam kegiatan pembelajaran, setiap proses pembelajaran terkandung nilai-nilai karakter tertentu sehingga guru bisa menggunakan strategi seperti diskusi, bimbingan kelompok bermain peran, tolking stik dan lain-lain, serta guru menjadi teladan bagi siswa dalam proses pembelajaran maupun di luar proses pembelajaran. Strategi bimbingan kelompok bermain peran dapat meningkatkan interaksi antara guru dan siswa (Ainah, Sarbani dan Adawlah, 2016). Menurut Ilahi (2014), Indonesia merupakan Negara yang mengalami kegagalan dalam implementasi pendidikan karakter. 
Lingkungan keluarga juga merupakan faktor yang mempengaruhi dan penentu bagi perkembangan anak. Bila pendidikan karakter ditanamkan sejak dini dan terus menerus seperti membiasakan bersikap sopan santun, bertanggung jawab, menghargai sesama dan tolong menolong, maka peserta didik dapat menjadi contoh tauladan yang baik bagi generasi berikutnya. Yang dimana bahwa keterlibatan orangtua dalam pemantauan perkembangan anak saat di rumah sangat penting, Sebab masa kanak-kanak adalah masa pembentukan pondasi dan masa kepribadian yang akan menentukan pengalaman anak selanjutnya. Menurut Roshita (2015) perilaku kurang sopan yang dilakukan anak dengan teman ataupun guru dibawa dari lingkungan rumah.

Guru perlu melakukan sebuah upaya atau merumuskan model khusus dalam mendidik para peserta didik menjadi generasi masa depan untuk meningkatkan karakter kesopanan, kejujuran dan tanggung jawab. Pada desain penelitian ini, sebuah model penanaman nilai menggunakan model secara sederhana sudah ada dan sudah diterapkan di sekolah tersebut, namun belum terlalu mendalam, karena pada hakikatnya merupakan sebuah model keteladanan.

Kegiatan dalam melaksanakan pendidikan karakter, dapat dilakukan melalui kegiatan pembelajaran yang inofatif seperti pembelajaran kontekstual. Penerapan pendidikan karakter dengan model kontekstual sangat cocok, karena pembelajaran kontekstual mengajak atau menghubungkan materi yang dipelajari dengan kehidupan nyata. Melalui pembelajaran kontekstual peserta didik dapat memperoleh hasil yang komperhensif tidak hanya pada aspek kognitif, tetapi juga pada aspek kognitif dan psikomotor.

\section{Pembiasaan Sopan Santun dan Pendidikan Karakter}

Memprihatinkan melihat generasi saat ini memiliki kepribadian yang tidak mencerminkan akhlak yang baik. Kesopanan terhadap orang yang lebih tua sudah mulai diabaikan. Selain kesopanan, nilai kejujuran serta tanggung jawab peserta didik juga mulai menipis. Menipisnya nilai kejujuran terlihat dari masih ada peserta didik yang berbohong ketika ditanya guru, ketika menemukan barang milik orang lain di kelas, mengakungaku barang milik orang lain maupun membuang sampah disembarang tempat, menyontek, alasan keluar masuk kelas, maupun alasan tidak mengerjakan PR.

Pendidikan karakter sebenarnya bukan merupakan hal baru bagi pendidikan di Indonesia. Jika kita tengok ke belakang proses pendidikan karakter sebenarnya telah dilakukan oleh para guru pada saat itu, bahkan pembiasaan sopan santun telah terjadi pada sat itu. Namun dengan perkembangan kehidupan semakin modern ini dan para guru yang pada saat itu telah diganti dengan guru-guru pada era modern nampaknya kecenderungan proses pendidikan lebih mengutamakan pada pendidikan untuk pencapaian kemampuan intektual semata. Proses 
pendidikan karakter seakan terlupakan. Sesuai dengan definisi bahwa, karakter sebagai pola perilaku bersifat individual dan keadaan moral seseorang (Daryanto dan Suyatri, 2013).

Proses pendidikan karakter bukan berarti pengubahan kurikulum atau menentukan satu bidang pelajaran tentang karakter, akan tetapi pendidikan karakter lebih pada proses pembentukan karakter siswa melalui penerapan dalam kehidupan di sekolah dan dirumah. Oleh karena itu proses pendidikan karakter ini semestinya dilakukan bersama antara orang tua di rumah dan pihak sekolah. Kerjasama dapat dilakukan dalam implementasi dan bembiasaan seperti yang dibahas dalam pembiasaan perilaku sopan santun dalam makalah ini.

Pada dasarnya pendidikan karakter di sekolah tidak dapat dikatakan tidaka ada sama sekali. Keberadaan matapelajaran agama, pendidikan moral pancasila, bimbingan dan penyuluhan adalah wujud nyata bahwa sekolah telah memberikan porsi pendidikan karakter pada siswa. Pendidikan karakter perlu sekali adanya kondisi yang menyenangkan dan suasana keakraban antara guru dan siswa. Sebagaimana dikemukakan oleh Thorndhike dalam teorinya "respon is strengthened if is rollowed by wet satisfying consequence and weakened if is follow wet by dissatisfying consequneces". Artinya "hubungan respon dan stimulasi akan bertambah erat bila disertai rasa senang dan puas serta sebaliknya kurang erat dan bahkan. Sesuai dengan teori ini hubungan respon antara siswa dan guru sangat penting untuk menerapkan dan mengembangkan pendidikan karakter sopan santun, dengan terjalinnya kedekatan antara siswa dan guru dengan adanya respon dari siswa dalam sistem pendidikan maka akan lebih meningkat lagi dan terjalin keharmonisan antara guru dan siswa-siswi.

Oleh karena itu, mungkin fokus penilaian pada mata pelajaran tersebut perlu ditambahkan dengan penilaian aspek efektif melalui pengamatan dari guru. Indikatorindikator peneilaain yang berkaiatan dengan pembentukan karakter siswa perlu dibuat agar arah dari pembentukan karakter siswa lebih mudah dilakukan dan terukur. Pembudayaan sikap sopan santun melalui pembiasaan yang dilakukan di sekolah dan di rumah melalaui kerjasama antara sekolah dan orang tua merupakan salah satu contoh bagaiama pendidikan karakter dapat dilakukan.

\section{Hambatan dalam Proses Penanaman Nilai Kesopanan, Kejujuran dan Tanggung Jawab}

Hambatan yang ditemui dalam penanaman nilai kesopanan, kejujuran, dan tanggung jawab yaitu dukungan orang tua untuk ikut berpartisipasi dalam pembiasaan rasa tanggung jawab peserta didik yang perlu untuk ditingkatkan. Peserta didik dirumah terbiasa melakukan sesuatu dengan bantuan asisten rumah tangga, sehingga kebiasaan tersebut masih terbawa hingga ke sekolah. 


\section{SIMPULAN}

Berdasarkan hasil penelitian, dan pembahasan maka dapat diperoleh beberapa kesimpulan bahwa anak-anak sekolah minggu GBI Sukma Medan yang menjadi informan penelitian peneliti ini, ketika mereka diwawancarai mengenai norma sopan santun dilihat bahwasannya mereka masih belum dapat menjelaskan apa itu norma sopan santun dengan jelas dan benar, serta beberapa dari mereka masih belum dapat juga menentukan dan memberikan contoh penerapan norma sopan santun dalam kehidupan sehari-hari.

Setelah diberikan pembinaan dengan teknik bercerita mengenai norma sopan santun, beserta dengan contoh penerapannya dalam kehidupan sehari-hari, ketika diwawancara kembali, dan memberikan pertanyaan yang khusus terkait dengan norma sopan santun, peneliti dapat menyimpulkan bahwasannya anak-anak sekolah minggu GBI Sukma Medan dapat mengerti dan mampu menjelaskan norma sopan santun, beserta dengan contoh penerapannya, dan disini peneliti sembari menyampaikan materi mengenai norma sopan santun, peneliti juga memberitahukan kepada mereka apa yang menyebabkan mereka masih kurang paham akan adanya norma sopan santun, dan peneliti memberikan penjelasan juga terkait permasalahan yang diakibatkan sehingga mereka kurang memahami norma sopan santun dengan baik.

\section{UCAPAN TERIMA KASIH}

Untaian kata terima kasih peneliti tuturkan atas selesainya penelitian ini kepada segenap anak-anak sekolah minggu GBI Sukma Medan yang telah sudi dan menerima peneliti untuk melakukan penelitian di GBI Sukma Medan. Terima kasih peneliti haturkan kepada para pengurus gereja GBI Sukma Medan, karena telah meluangkan waktunya dan memberi kesempatan kepada peneliti untuk dapat melakukan penelitian terhadap objek yang telah peneliti tentukan sebelumnya. Terima kasih peneliti haturkan kepada kedua orang tua peneliti atas segalanya doa dan kasih sayangnya, serta kepada dosen-dosen atas segala nasehat dan bimbingannya.

\section{DAFTAR PUSTAKA}

Adian, Donny. (2005). Percik Pemikiran Kontemporer: Sebuah Pengantar Komprehensif. Yogyakarta: Jalasutra.

Ainah., Sarbini., Rabiatul, A. (2016). Strategi guru PKn Menanamkan karakter sopan santun dalam pembelajaran pendidikan kewarganegaraan di SMP Negeri 3 Banjarmasin. Jurnal Pendidikan Kewarganegaraan. 6(11), 875-881.

Angelina, D. Y. (2013). Pola asuh otoriter, kontrol diri dan perilaku seks bebas remaja SMK. Persona: Jurnal Psikologi Indonesia, 2(2).

Bambang, P., \& Lina, M. (2006). Metode Penelitian Kuantitatif. Jakarta: PT Raja Grafindo Persada. Bertens, K (2007). Etika. Jakarta: Gramedia Pustaka Utama. 
Bungin, Burhan. (2007). Penelitian Kualitatif. Jakarta: Kencana Prenada Media Group.

Chazawi, A. (2007). Tindak Pidana Kesopanan. Jakarta : Rajawali Pers.

Cheung, N. W. T., \& Cheung, Y. W. (2008). Self-control, social factors, and delinquency. A test of the general of crime among adolescents in Hong Kong. Journal of Youth and Adolescence, 37(4), 412-430.

Cholid, N., \& Abu, A. (2009). Metode Penelitian. Jakarta: Bumi Aksara.

Daryanto, \& Suyatri Darmiyatun. (2013). Implementasi Pendidikan Karakter di Sekolah. Yogyakarta: Gava Media.

Ilahi, Mohammad Takdir. (2014). Peran Pendidikan Untuk Mengukuhkan Nasionalisme Dan Membangun Karakter Bangsa. Jurnal Pendidikan, 36 (76), 41-46.

Inrawati Paramata. (2015). Peran Pendidik Dalam Mengembangkan Sikap Sopan Santun Pada Anak Usia Dini Di Paud Muara Tenang Desa Posso Kecamatan Kwandang Kabupaten Gorontalo Utara. Gorontalo: Universitas Negeri Gorontalo.

Lickona, T. (2009). Educating for character: How our schools can teach respect and responsibility. Bantam.

M. Asrori. (2015). Perkembangan Peserta Didik; Pengembangan Kompetensi Pedagogis Guru. Yogyakarta: Media Akademi.

Marzuki., \& Fatma A.S. (2015). Teaching With Heart at the Green School in Era of Information Technology. Proceeding International Conference: Tuesday : May 12th 2015.

Muchlas dan Hariyanto. (2011). Konsep dan Model Pendidikan Karakter. Bandung: PT Remaja Rosdakarya..

Mulyana, Deddy. (2008). Metodologi Penelitian Kualitatif. Bandung: PT Remaja Rosda Karya.

Roshita. (2015). Upaya Meningkatkan perilaku sopan santun melalui layanan bimbingan kelompok dengan teknik sosidrama. Jurnal Penelitian Tindakan Bimbingan dan Konseling, 1(2), 2935.

Qiqi dan Rusdiana. (2014). Pendidikan Nilai; Teori dan Praktik di Sekolah. Bandung: Pustaka Setia.

Siti, S., Nihayatul, W. (2013). Filsafat, Etika, dan Kearifan Lokal. Geneva: Globethics. Net

Slameto. (2010). Belajar dan Faktor-Faktor yang Mempengaruhinya. Jakarta: Rineka Cipta.

Sunu, D. A., Ujiningsih. (2010). Pembudidayaan Sikap Sopan dan Santun di Rumah dan di Sekolah

Sebagai Upaya untuk Meningkatkan Karakter Siswa. Temu Ilmiah Nasional: Universitas Terbuka.

Winataputra, U.S. (2014). Diskursus Aktual Tentang Paradigma Pendidikan Kewarganegaraan (PKn) Dalam Konteks Kurikulum 2013. Bahan Diskusi dalam Semnas PKn-AP3KnI.

Zuriah, N. (2007). Pendidikan Moral dan Budi Pekerti Dalam Perspektif Perubahan. Jakarta: Bumi Aksara.

Zuriah, N., \& Yustianti, F. (2007). Pendidikan moral \& budi pekerti dalam perspektif perubahan: menggagas platform pendidikan budi pekerti secara kontekstual dan futuristik. Jakarta: Bumi Aksara. 